\title{
STIMULATION OF CHILDREN GROWTH AS A RESULT OF TSUNAMI IMPACT SOUTH SUNDA PANDEGLANG BANTEN
}

\author{
Sugeng Wiyono ${ }^{1)}$, Iskari Ngadiarti ${ }^{1)}$, Isti Rusdiyani ${ }^{2)}$ \\ 1)Politeknik Kesehatan Kemenkes Jakarta II \\ ${ }^{2)}$ Universitas Tirtayasa Kemenristekdikti Banten
}

Corespondent: sugeng_gizi@yahoo.com

Submitted: 24 November 2019 ; Accepted: 21 December 2019

https://doi.org/10.36525/sanitas.2019.13

\begin{abstract}
The cause of malnutrition is not only caused by lack of food intake but also because of infection. Another factor that isestimted to influence nutritional status is parenting. This study aims to find out the effect of mother class programs and chil preschool toward mother's knowledge, parenting, children's nutritional intake, and childrens nutritional status. The hypothesis of this study is the intervention of the mother class program and pre school plays better than the intervention of the mother class only or toward the mother's knowledge and nutritional status of the child. The chosen sample was children aged 2-6 years the inclusion and exclusion criterias. This study uses a quasi-experimental design. The sample was divided into 3 groups, mother group class, pre school and mother and child play class. The results showed $73.3 \%$ of female research subjects, an average age of 55.84 months, $13.3 \%$ diarrhea, $2.2 \%$ ARI, $66.7 \%$, coughs, $86.7 \%$ colds/flu, and $55.6 \%$ of children were permissively care. At the end of the treatment an in body weight increase, height of the child, the greatest nutritional status occurred in pre school. At the end of the treatment the intake of nutrients in energy, protein, the fast is greatest fast is pre school group for the greatest intake of carbohydrates in the maternal class group. Health and nutrition education needs to be carried out on an ongoing basis to maintain the spirit of the mother to carry out health care for children and other families. It is necessary to find a form of playing patterns that can make a child enthusiasm for learning.
\end{abstract}

Keywords: Tsunami, nutritional status, intake, children under five

This is an open access journal, and articles are distributed under the terms of the Creative Commons Attribution-NonCommercial-ShareAlike 4.0 License, which allows others to remix, tweak, and build upon the work non-commercially, as long as appropriate credit is given and the new creations are licensed under the identical terms. C2019 Sanitas

\section{STIMULASI TUMBUH ANAK BALITA AKIBAT DAMPAK TSUNAMI SELAT SUNDA PANDEGLANG BANTEN}

\footnotetext{
ABSTRAK

Penyebab gizi kurang tidak hanya disebabkan oleh asupan makanan yang kurang tetapi juga karena infeksi. Faktor lain yang diduga mempengaruhi status gizi adalah pola pengasuhan anak. Penelitian ini bertujuan untuk mengetahui pengaruh program kelas ibu dan kelas anak bermain terhadap pengetahuan ibu, pola asuh ibu, asupan zat gizi anak, dan status gizi anak. Hipotesis penelitian ini yaitu intervensi program kelas ibu dan anak bermain lebih baik dibandingkan dengan intervensi kelas ibu saja atau kelas anak bermain saja terhadap pengetahuan ibu dan status gizi anak. Sampel yang dipilih yaitu anak berusia 2-6 tahun memenuhi kriteria inklusi dan eksklusi. Penelitian ini menggunakan desain kuasi eksperimen. Sampel dibagi menjadi 3 kelompok, yaitu kelompok kelas ibu, kelas anak bermain dan kelas ibu dan
} 
anak bermain. Hasil penelitian menunjukkan sebesar $73.3 \%$ subjek penelitian perempuan, umur rata-rata 55,84 bulan, $13.3 \%$ menderita diare, $2.2 \%$ menderita ISPA, $66.7 \%$ menderita batuk, 86.7 $\%$ menderita pilek/flu, dan 55.6\% anak diasuh secara permisif. Pada akhir perlakuan terjadi peningkatan berat badan, tinggi badan anak, status gizi terbesar terjadi pada kelompok kelas anak bermain. Pada akhir perlakuan asupan zat gizi energi, protein, lemak terbesar pada kelompok kelas anak bermain, untuk asupan karbohidrat terbesar pada kelompok kelas ibu. Perlu dilakukan pendidikan kesehatan dan gizi secara berkelanjutan untuk menjaga semangat ibu untuk melalukan perawatan kesehatan anak dan keluarga lainnya. Perlu dicari bentuk pola bermain yang dapat membuat semangat belajar anak.

Kata Kunci: Tsunami, status gizi, asupan, balita

\section{PENDAHULUAN}

Gelombang Tsunami melanda Banten dan Lampung pada 22 Desember 2018, menyebabkan korban meninggal mencapai 429 jiwa, 1.485 orang terluka dan 154 orang dinyatakan hilang. Kerusakan rumah dan fasilitas umum secara tidak langsung akan mempengaruhi ketersediaan makanan, sumber air bersih, sarana Mandi Cuci Kakus (MCK) dan lainnya. Hal tersebut berefek pula terhadap status kesehatan dan gizi masyarakat terutama terutama anak balita, dimana rentan terhadap berbagai penyakit khususnya penyakit infeksi dan gizi kurang. Dampak lanjut dari hal tersebut akan menyebabkan terjadinya gangguan tumbuh kembang pada anak (1). Gangguan pertumbuhan sering diindikasikan dengan pengukuran fisik yaitu pengukuran antropometri. Prevalensi status gizi kurang-buruk di Provinsi Banten berdasarkan hasil Riskesdas 2018 sebesar 17,2\% dan menjadi salah satu masalah kesehatan masyarakat karena angkanya mendekati prevalensi tinggi (20\%). Sementara itu, prevalensi balita pendek di Provinsi Banten sebesar 33\% yang terdiri dari 16,4\% sangat pendek dan 16,6\% pendek. Kabupaten dengan prevalensi balita pendek tertinggi di Provinsi Banten ada di Kabupaten Pandeglang (38,6\%) (2). Diperkirakan jumlah pengungsi lebih dari 80 kepala keluarga, ada sekitar 100 balita yang sebagian besar status gizinya baik dan terdapat kurang lebih $7 \%$ balita dengan gizi kurang-buruk serta 6 orang ibu hamil (1).

Beberapa laporan menyatakan bahwa beragam jenis penyakit mulai menyerang para pengungsi bencana Tsunami Selat Sunda di Kabupaten Pandeglang, Banten. Posko Kemensos Carita. Infeksi Saluran Pernapasan Akut (ISPA) merupakan salah satu penyakit yang paling banyak diderita oleh pengungsi (1). Penyakit ISPA merupakan penyakit yang mudah menular dan dapat dicegah dengan asupan gizi yang cukup serta Perilaku Hidup Bersih Sehat (PHBS) dari warga pengungsi (2). Penyebab gizi kurang tidak hanya disebabkan oleh makanan yang kurang saja tetapi juga karena adanya penyakit infeksi. Anak yang mendapat cukup makanan tetapi sering terkena diare atau penyakit infeksi dapat menderita kurang gizi. Faktor lain yang 
diduga mempengaruhi status gizi adalah pola asuh pada anak. Pola pengasuhan, selain mempengaruhi pertumbuhan juga mempengaruhi perkembangan pada anak. Kelas ibu dan anak bermain merupakan wadah ibu berkumpul bersama-sama untuk berdiskusi, tukar pendapat dan pengalaman terkait masalah kesehatan, gizi dan tumbuh kembang anaknya. Dalam kelas ibu dan anak bermain juga ditekankan pentingnya pola asuh yang benar dalam memberikan perhatian penuh dan kasih sayang pada anak dengan memberinya waktu yang cukup untuk menikmati kebersamaan dengan seluruh anggota keluarga, disamping pengetahuan dan praktek tentang bagaimana menyiapkan makanan yang baik untuk anak.

Beberapa bentuk permainan anak yang merangsang perkembangan dan pertumbuhan antara lain bermain balok puzle, bermain bola dan origami(3). Zat gizi dibutuhkan untuk menunjang kemampuan otak dan daya tahan tubuh sedangkan stimulasi dibutuhkan sebagai pengalaman dini anak dan juga proses tumbuh kembangnya. Melalui kombinasi yang tepat antara zat gizi dan stimulasi sejak dini, maka anak dapat tumbuh dan berkembang secara maksimal dan normal yang ditandai dengan kemampuan seimbang antara fisik, mental, emosi, kemampuan berbahasa, kecerdasan dan tingkah laku, sehingga menghasilkan generasi yang mumpuni (4). Tujuan umum untuk Mengetahui pengaruh program kelas ibu balita dan anak bermain terhadap status gizi balita serta pola asuh ibu pada wilayah yang terkena dampak Tsunami di Kabupaten Pandeglang, Provinsi Banten. Sedangkan Tujuan khusus yaitu mengidentifikasi karakteristik responden, mengidentifikasi status gizi balita sebelum dan sesudah mengikuti program kelas ibu balita dan anak, menganalisis perbedaan pengetahuan ibu, perbedaan asupan zat gizi, perbedaan status gizi. Hipotesis Penelitian adalah intervensi program kelas ibu balita dan anak bermain lebih baik dibandingkan dengan intervensi kelas ibu balita saja atau kelas anak bermain saja terhadap status gizi, tumbuh kembang balita. Untuk membuktikan hipotesis penelitian digunakan Uji t pasangan dan Uji Anova (5)(6).

\section{METODE PENELITIAN}

Desain penelitian ini yaitu penelitian eksperimental dengan jenis eksperimental, merupakan modifikasi kondisi yang dilakukan secara itu sendiri serta pengamatan terhadap perubahan yang terjadi pada peristiwa sengaja dan terkontrol dalam menentukan peristiwa atau kejadian, serta pengamatan (7). Kriteria Inklusi : Anak berumur 0-59 bulan, tinggal menetap di Desa Sukarame, tidak mengalami komplikasi penyakit baik menular maupun tidak menular, Ibu balita bersedia menandatangani inform concent (8). Kriteria Ekslusi : Balita menderita komplikasi penyakit baik menular maupun tidak menular, Balita penderita kelainan 
perkembangan mental, Balita mengalami kelainan postur tubuh sehungga tidak dapat dilakukan pengukuran, Ibu balita tidak bersedia menandatangani inform consent (9).

\section{HASIL DAN PEMBAHASAN}

Karakteristik orangtua responden terdiri atas pekerjaan ayah sebagian besar sebagai buruh sebanyak $51.1 \%$, ibu responden sebagian besar sebagai ibu rumah tangga $(71.1 \%)$, terbanyak pendidikan ayah dan ibu Sekolah Dasar masing-masing 44.4\%, dan 51.1\%, sebagian besar (48.0\%), dengan pendapatan Rp 500.000 sd Rp.1.000.000. Sampel terjadi pembagian secara proporsional jenis kelamin setiap kelompok yaitu laki-laki sebesar 26,7\% dan perempuan sebanyak 73,3\%. Untuk umur anak rata-rata tertinggi pada kelompok sampel anak bermain yaitu $64,0 \pm 5,8$ bulan, umur terendah pada kelompok sampel kelas ibu yaitu 46,1 $\pm 8,5$ bulan. Rata-rata berat badan anak tertinggi pada kelompok anak bermain yaitu sebesar $17,4 \pm 1,7 \mathrm{~kg}$, sedangkan rata-rata tinggi badan tertinggi pada kelompok anak bermain yaitu $106,3 \pm 4,1 \mathrm{~cm}$. Untuk lebih detail terlihat pada tabel dibawah ini.

Tabel 1. Karakteristik Anak

\begin{tabular}{|c|c|c|c|c|c|c|c|}
\hline \multirow[t]{2}{*}{ Karakteristik } & \multirow[t]{2}{*}{ Kategori } & \multicolumn{2}{|c|}{$\begin{array}{l}\text { Kelas Ibu dan } \\
\text { Anak bermain } \\
\quad(\mathrm{n}=15)\end{array}$} & \multicolumn{2}{|c|}{$\begin{array}{l}\text { Kelas Ibu } \\
(\mathrm{n}=15)\end{array}$} & \multicolumn{2}{|c|}{$\begin{array}{l}\text { Anak Bermain } \\
\qquad(\mathrm{n}=15)\end{array}$} \\
\hline & & $\mathrm{n}$ & $\%$ & $\mathrm{n}$ & $\%$ & $\mathrm{n}$ & $\%$ \\
\hline \multirow[t]{2}{*}{ Jenis Kelamin } & Laki-laki & 4 & 26,7 & 4 & 26,7 & 4 & 26,7 \\
\hline & Perempuan & 11 & 73,3 & 11 & 73,3 & 11 & 73,3 \\
\hline Umur (Bl) & Rata-rata \pm SD & \multicolumn{2}{|c|}{$57,3 \pm 6,9$} & \multicolumn{2}{|c|}{$46,1 \pm 8,5$} & \multicolumn{2}{|c|}{$64,0 \pm 5,8$} \\
\hline $\begin{array}{l}\text { Berat Badan }(\mathrm{kg}) \\
\text { Sebelum Intervensi }\end{array}$ & Rata-rata \pm SD & \multicolumn{2}{|c|}{$14,8 \pm 3,3$} & \multicolumn{2}{|c|}{$13,9 \pm 3,1$} & \multicolumn{2}{|c|}{$17,4 \pm 1,7$} \\
\hline $\begin{array}{l}\text { Berat Badan }(\mathrm{kg}) \\
\text { Sesudah Intervensi }\end{array}$ & Rata-rata $\pm \mathrm{SD}$ & \multicolumn{2}{|c|}{$14,9 \pm 3,3$} & \multicolumn{2}{|c|}{$14,2 \pm 3,0$} & \multicolumn{2}{|c|}{$17,5 \pm 1,7$} \\
\hline $\begin{array}{l}\text { Tinggi Badan }(\mathrm{cm}) \\
\text { Sebelum Intervensi }\end{array}$ & Rata-rata \pm SD & \multicolumn{2}{|c|}{$98,7 \pm 5,9$} & \multicolumn{2}{|c|}{$97,8 \pm 7,3$} & \multicolumn{2}{|c|}{$106,3 \pm 4,1$} \\
\hline $\begin{array}{l}\text { Tinggi Badan }(\mathrm{cm}) \\
\text { Sesudah Intervensi }\end{array}$ & Rata-rata \pm SD & \multicolumn{2}{|c|}{$98,9 \pm 5,8$} & \multicolumn{2}{|c|}{$94,0 \pm 7,3$} & \multicolumn{2}{|c|}{$106,6 \pm 4,0$} \\
\hline
\end{tabular}

Untuk jenis penyakit yang diderita anak selama penelitian persentase tertinggi berdasarkan kelompok perlakuan yaitu berturut-turut diare pada kelompok kelas ibu sebesar $20,0 \%$, ISPA pada kelompok anak bermain sebesar 6,7\%, batuk pada kelompok kelas ibu dan anak bermain yaitu 80,0\% dan flu/pilek pada kelompok kelas ibu dan anak bermain sebesar 
$93,3 \%$, sedangkan pola pengasuhan terbanyak adalah pola pengasuhan pada secara permisif sebesar $66,7 \%$ pada kelompok kelas ibu. Uraian lebih detail terlihat pada grafik sebagai berikut.

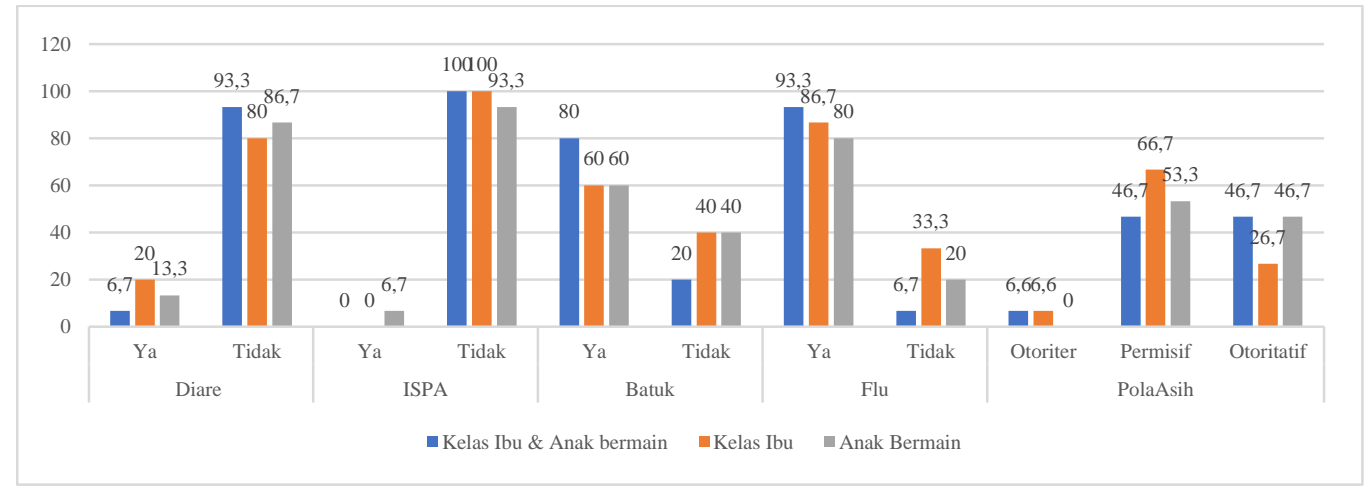

Gambar 1. Jenis Penyakit Anak

Untuk karakteristik orang tua terdapat variasi tingkat pendidikan ayah dan ibu, pada kelompok kelas ibu dan anak bermain terbanyak ayah dengan tingkat pendidikan SD sebesar 46,7\%, untuk kelompok kelas ibu terbanyak ayah dengan tingkat Pendidikan SMP (46,\%), sedangkan pada kelompok anak bermain terbanyak ayah dengan tingkat pendidikan SD 53,3\%. Sedangkan untuk ibu, pada kelompok kelas ibu dan anak bermain ibu dengan tingkat pendidikan SD dan SMA/SMK masing-masing sebesar 40,0\%, pada kelompok kelas ibu terbanyak ibu dengan tingkat pendidikan SMP sebesar 46,7\% dan pada kelompok anak bermain tertinggi ibu dengan tingkat pendidikan SD dan SMP masing-masing 40.0\%. Untuk jenis pekerjaan ayah terbanyak sebagai buruh/petani yaitu masing-masing 33,3\% pada kelompok kelas ibu dan anak bermain, sebesar 53,3\% pada kelompok kelas ibu dan sebesar 66,7\% pada kelompok anak bermain. Untuk pekerjaan ibu terbanyak ibu sebagai ibu rumah tangga yaitu masing-masing pada kelas ibu dan anak bermain sebesar 66,7\%, pada kelompok kelas ibu sebesar $80,0 \%$ dan pada kelompok anak bermain sebesar 73,4\%. Sedangkan untuk pendapatan keluarga pada kelompok kelas ibu dan anak bermain dan kelompok kelas ibu terbanyak pendapatan Rp 500.000 sd. 1.000 .000 yaitu masing-masing sebear 53,3\% dan 60,0\%, sedangkan pada kelompok anak bermain terbanyak keluarga dengan pendapatan Rp 1.000.000 sd. Rp 1.500.000 sebesar 40.0\%.

Untuk mengetahui dampak perlakuan maka dilakukan pengukuran pengetahuan pre dan post tes setiap minggu seperti terlihat pada gambar sebagai berikut ini. Hasil pengukuran pre dan pos tes pengetahuan ibu pada setiap kelompok perlakuan menunjukkan terjadi peningkatan nilai. 
Tabel 2. Karakteristik orangtua responden
Karakteristik
Kategori
Kelompok

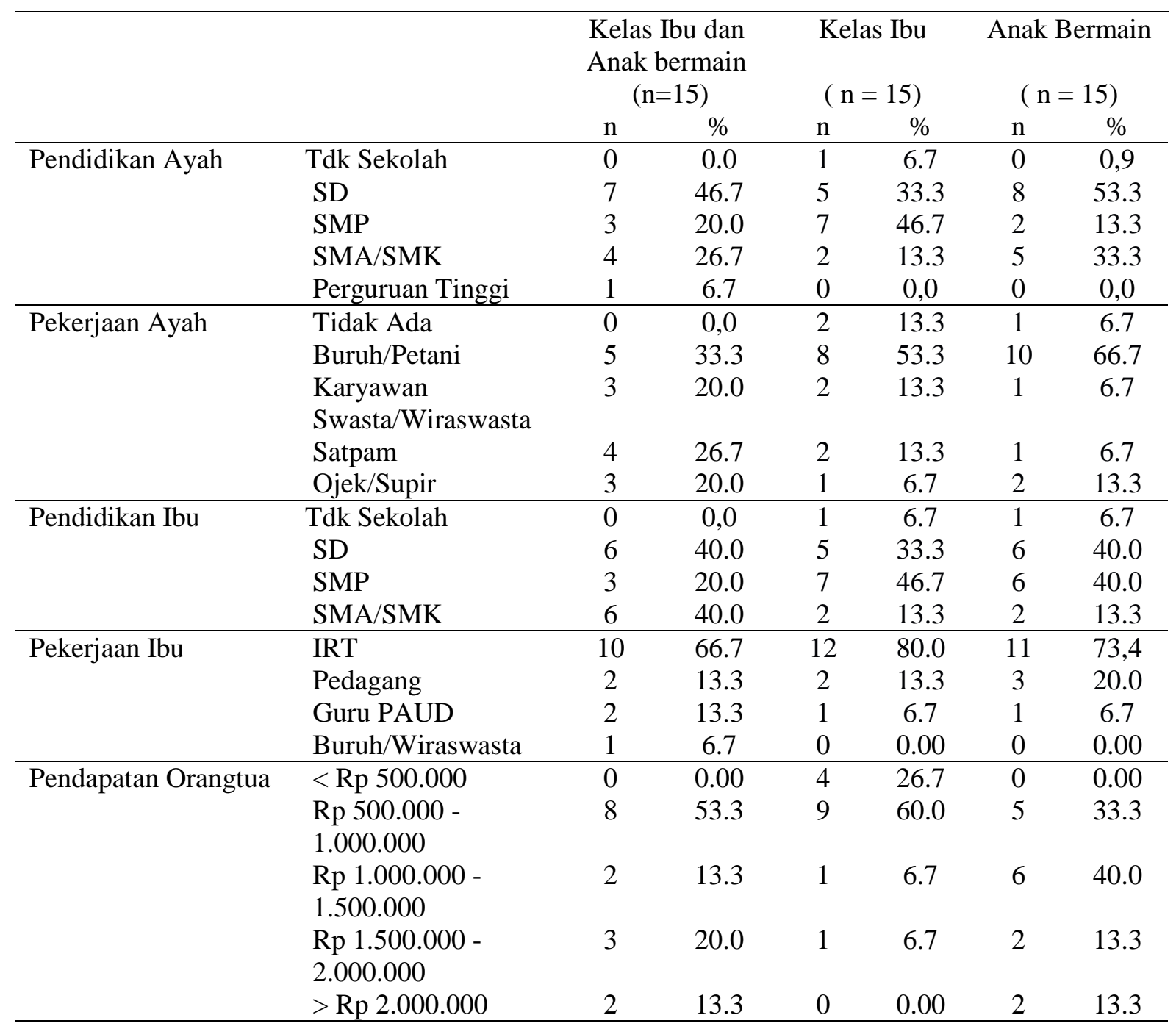

Pada kelompok kelas ibu dan anak bermain pada pertemuan minggu III tidak menunjukkan peningkatan nilai dan pada pertemuan minggu ke IV malah terjadi penurunan nilai post tes. Pada kelompok kelas ibu menunjukkan selalu terjadi peningkatan nilai selama 4 minggu berturut-turut, sedangkan kelompok anak bermain sebagai kontrol nilai pre tes paling rendah dibanding kelompok lainnya. 


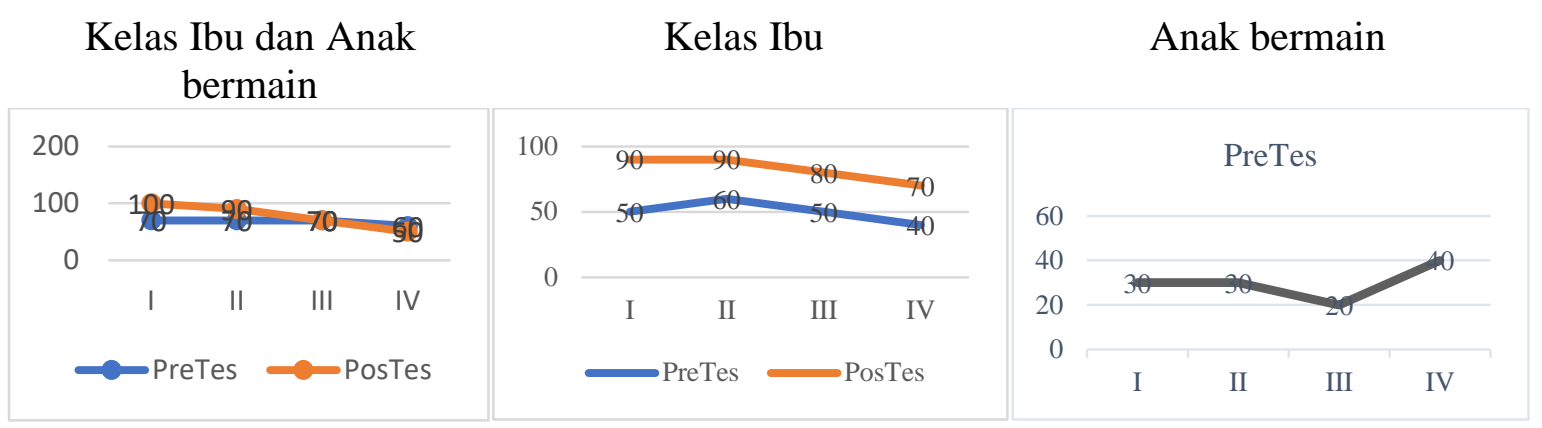

Gambar 2. Kecenderungan nilai pre dan pos tes

Selanjutnya adalah nilai parameter lain sebeluim dan susudah dilakuan intervensi, Setelah dilakukan perlakuan menunjukkan bahwa terjadi peningkatan pengetahun pada kelompok kelas ibu. Hal ini sesuai denghan hasil penelitian Septi Fitrah Ningtyas (E.d) bahwa ada efek kelas ibu 0-59 bulan untuk perilaku pemanfaatan buku KIA (10)

Tabel 3. Nilai Awal dan Akhir dampak perlakuan

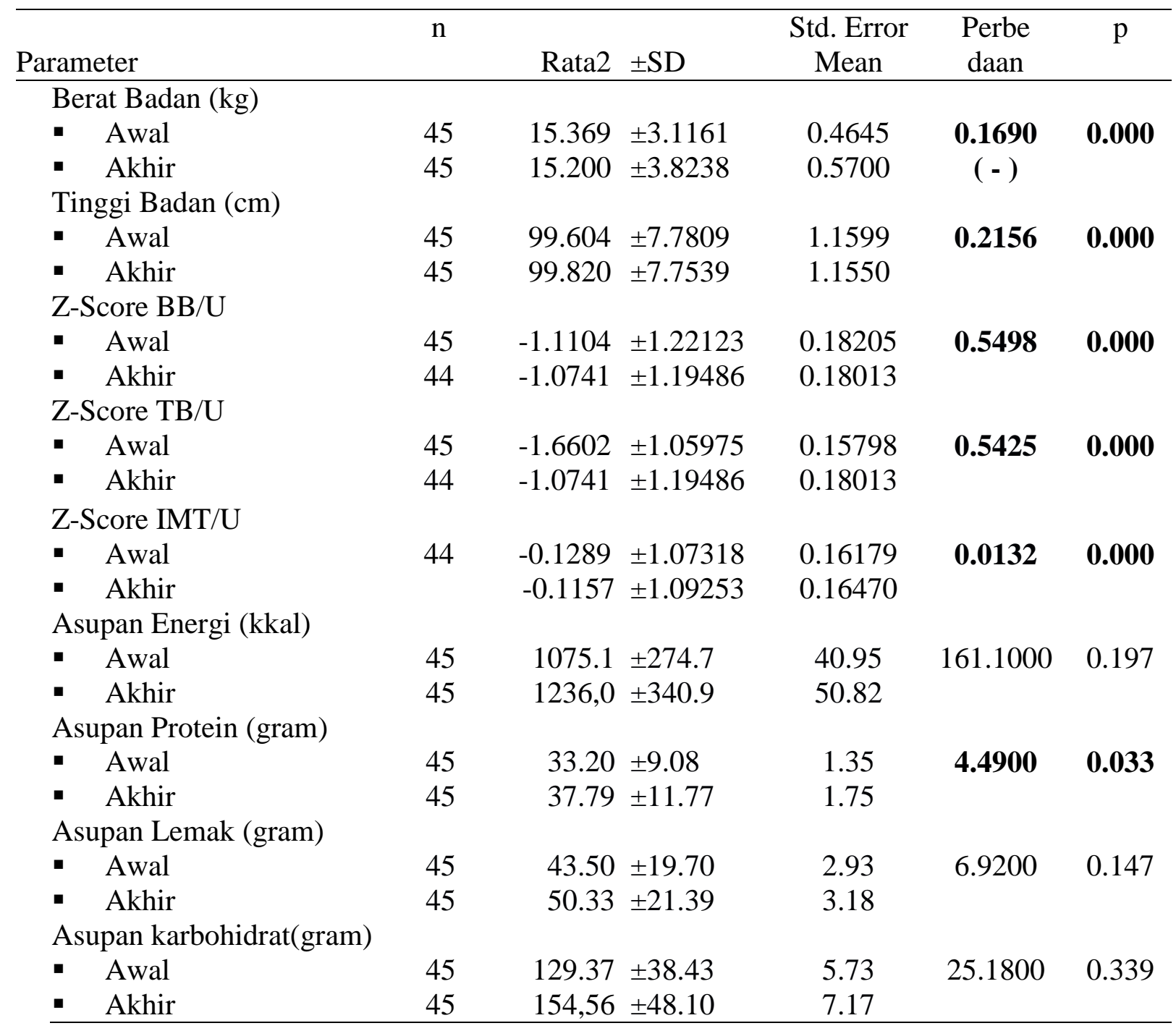


Hasil penelitian Linda Meliati (E.d) dan menyatakan bahwa setelah dilakukan kelas ibu balita rata - rata skor pengetahuan naik sebanyak 0.33 (11). Hasil penelitian Diyan Indrayani, dkk (2019) menunjukkan bahwa kelas ibu balita berpengaruh terhadap peningkatan pengetahuan dan keterampilan ibu dalam stimulasi tumbuh kembang balita dengan nilai $\mathrm{p}<$ 0,05. Responden yang mengikuti kelas ibu mengalami peningkatan pengetahuan sebesar 15,8 $\%$ dibandingkan dengan sebelum mengikuti kelas ibu balita. Proses belajar dengan kelas ibu balita yang mengandalkan sumber belajar dari pengalaman peserta dan peran fasilitator dalam mengungkapkan pengalaman sebagai sumber belajar merupakan metode yang efektif dalam meningkatkan pengetahuan dan keterampilan (12). Setelah diberikan perlakuan menunjukkan bahwa secara bermakna $(\mathrm{p}=0.000)$ terjadi penurunan berat badan anak sebesar $0.1690 \mathrm{~kg}$, hal ini salah satu penyebabnya adalah beberapa anak menderita sakit. Untuk tinggi badan anak, hasil uji menunjukkan bahwa secara bermakna $(\mathrm{p}=0.000)$ terdapat peningkatan rata-rata tinggi badan anak sebesar 0,2159 cm. Hasil tersebut bertentangan dengan Nur Agustiningsih (2017) yang menunjukkan bahwa tidak ada perbedaan kasus bayi lahir BBLR antara subjek yang mengikuti kelas ibu hamil dan yang tidak mengikuti kelas ibu hamil (13). Hal ini kemungkinan orangtua telah menerapkan pendidikan gizi seimbang yang diterima selama proses penelitian berlangsung, dimana orang tua memberikan anak lauk-pauk seperti ikan, daging, hati, tahu, tempe sebagai sumber protein. Lingkungan pantai sebagai penghasil ikan juga turut mendukung sebagai penghasil makanan sumber protein. Protein sangat dibutuhkan untuk pertumbuhan penambahan panjang tulang pada tubuh anak. Selain faktor asupan kemungkinan juga dampak dari perlakuan yaitu stimulus permainan berupa gerakan loncat yang dapat memacu pertumbuhan tulang. Untuk status gizi anak juga menunjukkan terjadi peningkatan nilai ZScore, masing-masing BB/U terjadi peningkatan ZScore $0.5498(\mathrm{p}=0,000), T B / \mathrm{U}$ terjadi peningkatan ZScore 0.5425 ( $\mathrm{p}=0,000)$, IMT/U terjadi peningkatan ZScore 0.0132 ( $\mathrm{p}=0,000)$. Hal tersebut bertentangan dengan hasil penelitian Suryana dan Yulia Fitri (2017) dan Deni Aditya Christianto, dkk (2018) yang menyatakan bahwa tidak menunjukkan hubungan yang signifikan anatara aktivitas fisik dengan IMT dan komposisi lemak tubuh. (14)(15). Sebaliknya penelitian Andika Rikarno, dkk (2017) dan Koko Nugroho, dkk (2016), menunjukkan bahwa ada hubungan antara IMT siswa dengan aktivitas fisik (16)(17). Untuk zat gizi terjadi peningkatan asupan masing-masing untuk energi sebesar 161,1 kkal ( $\mathrm{p}=0.197)$, asupan protein meningkat sebesar 4.49 gram ( $\mathrm{p}=0.033)$, asupan lemak meningkat 6.92 gram ( $\mathrm{p}=0.147)$, dan asupan karbohidrat meningkat sebesar 25.18 gram $(\mathrm{p}=0.339)$. Penyebab peningakatan asupan 
zat gizi kemungkinan meningkatnya pengetahuan dan kesadaran ibu untuk memenuhi kebutuhan asupan zat gizi anak. Ada pengaruh program kelas ibu balita terhadap pengetahuan ibu ( $\mathrm{p}=0.0001)$, pola asuh $(\mathrm{p}=0.002)$, asupan zat gizi (energi, protein, lemak, karbohidrat) masing-masing $(\mathrm{p}=0.0001)$, pola makan $(\mathrm{p}=0.0001)$ dan status gizi $(\mathrm{p}=0.001)$. Hal ini sesuai dengan hasil penelitian Wida Kurnia (2018) bahwa program kelas ibu balita memiliki pengaruh terhadap pengetahuan ibu, pola asuh, asupan zat gizi, pola makan dan status gizi pada balita gizi buruk (BB/U) usia 0-59 bulan (18). Penelitian Cut Rika Fitria Ananda, dkk (2017) juga menyimpulkan bahwa terdapat hubungan status gizi dengan fisik motorik anak (19). Sri Daya Ayu (2000) juga menyimpulkan bahwa program pendampingan gizi meningkatkan pengetahuan gizi ibu, pola pengasuhan, dan status gizi pada 3 bulan setelah pendampingan (20).

\section{SIMPULAN}

Sebagian besar jenis kelamin subjek penelitian perempuan, sebagian subjek menderita diare, menderita ISPA, menderita batuk, menderita pilek/flu, subjek diasuh secara permisif. Terjadi peningkatan tinggi badan anak, terjadi peningkatan status gizi anak untuk indeks BB/U, TB/U, IMT/U, terjadi peningkatan skor perkembangan anak, terjadi peningkatan asupan zat gizi energi, protein, lemak dan karbohidrat. Pada akhir perlakuan peningkatan berat badan, tinggi badan anak, status gizi BB/U, TB/U, IMT/U, dan perkembangan terbesar terjadi pada kelompok kelas anak bermain. Pada akhir perlakauan asupan zat gizi energi, protein, lemak terbesar pada kelompok kelas anak bermain, untuk asupan karbohidrat terbesar pada kelompok kelas ibu.

\section{SARAN}

Perlu selalu dilakukan pendidikan kesehatan dan gizi secara berkelanjutan untuk menjaga semangat ibu untuk melakukan perawatan kesehatan anak dan keluarga lainnya. Kepada orang tua perlu ditingkatkan upaya pemberian makanan sumber protein disertai stimulus gerakan loncat yang untuk merangsang pertumbuhan tulang untuk menambah tinggi badan anak, kemudian Perlu dicari bentuk pola bermain yang dapat membuat anak semangat belajar.

\section{DAFTAR PUSTAKA}

1. Kemenkes RI K. Tsunami Selat Sunda. 2018;

2. Kemenkes R,I Riset Kesehatan Dasar 2018 
3. Dinkes Kota Medan DK. Hasil Stimulasi Deteksi dan Intervensi Tumbuh Kembang (SDIDTK) Balita di Kota Medan. 2015;

4. Wawan, (Ed); Orangtua Indonesia Masih Gagap dalam Pola Asuh Anak. 2014. p. 1.

5. Muhson, Ali; Pedoman Praktikum Analisis Statistik; Fakultas Ekonomi Universitas Negeri Yogyakarta ;2016

6. Basuki, Agus Tri (E.d); Analisis Of Varians Bahan Ajar Statistika ; Universitas Muhammadiyah Yogyakarta

7. Soendari T. (Ed); Metode penelitian eksperimen.

8. ...........; Meninjau Kriteria inklusi dan eksklusi dalam pengambilan sampel untuk penelitian.

9. Pakendek, Adriana (E.d); Informed Consent Dalam Pelayanan Kesehatan; Fakultas Hukum Universitas Madura Pamekasan, email:adri.pakendek@gmail.com

10.Ningtyas, Septi Fitrah; Pengaruh Kelas Ibu Balita Usia 0-59 Bulan Terhadap Pengetahuan Pemanfaatan Buku KIA; Jurnal Keperawatan \& Kebidanan - STIKES Dian Husada Mojokerto p $63-71$

11. Indrayani, Diyan ; Titi Legiati; Desi Hidayanti; Kelas Ibu Balita Meningkatkan Pengetahuan dan Keterampilan Ibu dalam Stimulasi Tumbuh Kembang; Jurnal Kesehatan Prima http://jkp.poltekkes-mataram.ac.id/index.php/home/index p-ISSN: 1978-1334 (Print); e-ISSN: 2460-8661 (Online)

12.Meliati, Linda; Ni Putu Karunia Ekayani; Pengaruh Pelaksanaan Program Kelas Ibu Balita Terhadap Pengetahuan Dan Sikap Ibu Dalam Deteksi Tumbuh Kembang Balita; Jurusan Kebidanan, Poltekkes Kemenkes Mataram.

13.Agustinngsih, Nur; Efektifitas Program Pembelajaran Kelas Ibu Hamil Terhadap Pengetahuan Gizi, Status Anemia, Kek Dan Berat Bayi Lahir Rendah Di Kecamatan Grogol Kabupaten Sukoharjo; Program Studi S1 Gizi Fakultas Ilmu Kesehatan Universitas Muhammadiyah SurakartA 2017

14. Suryana, Yulia Fitri; Hubungan Aktivitas Fisik Dengan IMT Dan Komposisi Lemak Tubuh (The Association Between Physical Activity with Body Mass Index (BMI) and Body Fat Composition); Jurnal AcTion: Aceh Nutrition Journal, November 2017; 2(2): 114-119P-ISSN : 2527-3310; E-ISSN : 2548-5741

15. Deni Aditya Christianto, dkk; Hubungan Aktivitas Fisik Terhadap Kejadian Obesitas Berdasarkan Indeks Massa Tubuh Di Desa Banjaroyo Kulon Progo Daerah Istimewa Yogyakarta. Berkala Ilmiah Kedokteran Duta WacanaDiterima: 29-01-2018 • Disetujui : 18-10-2018 http://dx.doi.org/10.21460/bikdw.v3i2.97

16. Andika Rikarno Putra, dkk; Hubungan Aktivitas Fisik Dan Waktu Di Depan Layar Elektronik Dengan Indeks Massa Tubuh Siswa SD Islam Hidayatullah Semarang; Jurnal Kesehatan Masyarakat (e-Journal) Volume5, Nomor1, Januari 2017 (ISSN: 2356-3346) http://ejournal-s1.undip.ac.id/index.php/jkm

17. Nugroho, Koko; Mulyadi; Gresty Natalia Maria Masi; Hubungan Aktivitas Fisik Dan Pola Makan Dengan Perubahan Indeks Massa Tubuh Pada Mahasiswa Semester 2 Program Studi Ilmu Keperawatan Fakultas Kedokteran; . e-journal Keperawatan(e-Kp) Volume 4 Nomor 2, Juli 2016

18.Kurnia, Wida, Pengaruh Program Kelas Ibu Balita Terhadap Pengetahuan Ibu, Pola Asuh, Asupan Zat Gizi, Pola Makan Dan Status Gizi Pada Balita Gizi Buruk (Bb/U) Usia 0-59 Bulan Di Wilayah Kerja Puskesmas Picung Tahun

19. Ananda, Cut Rica Fitriya; Hasanuddin; Hafnati Rahmatan; Hubungan Status Gizi Dengan Fisik Motorik Anak Tk Fkip Unsyiah Darussalam Banda Aceh; Jurnal Ilmiah Mahasiswa Fakultas Keguruan dan Ilmu Pendidikan Unsyiah Vol 2, No 2 (2017); Mei 
2017

20. Ayu, Sri Dara; Pengaruh Program Pendampingan Gizi Terhadap Pola Asuh, Kejadian Infeksi Dan Status Gizi Balita Kurang Energi Protein; 2008 